\title{
Energy drinks - consumption and awareness among students of Medical University of Lublin
}

\author{
Piotr Cencek, Ewelina Wawryk-Gawda ${ }^{*}$, Patryk Samborski, Barbara Jodlowska-Jedrych
}

Chair and Department of Histology and Embryology with Experimental Cytology Unit, Medical University of Lublin, Radziwiłłowska 11, 20-080 Lublin, Poland

\section{ARTICLE INFO \\ Received 05 July 2016 \\ Accepted 20 October 2016}

\section{Keywords:}

energy drink,

students,

caffeine,

taurine.

\begin{abstract}
Energy drinks (ED), containing caffeine, taurine and another substances, are one of the more frequently used legal stimulants. Still, because these can endanger consumers' health, it is thought that their marketing should be legally controlled.

In our study, we analyzed the frequency of energy drink consumption, as well as the knowledge held about these drinks among medicine and dentistry students of the Medical University of Lublin. In the study, 131 students participated, and the study was done in the form of a survey. The results of this indicate that 81 students $(61.83 \%)$ declared a daily consumption, and most respondents $(78.48 \%)$ stated at least a one time consumption of 250 to $749 \mathrm{ml}$ of energy drink. What is more, $26.25 \%$ of respondents combined ED with other substances, most frequently with coffee and alcohol. Regarding knowledge of ED effects, contents and side effects, more males than females actively sought and held this information. Furthermore, more than half of all respondents believed that the availability of EDs in Poland should be limited.

Our study showed that the awareness of the effects and mechanisms of action of EDs, among the questioned students is relatively high. Nevertheless, they frequently consume EDs and combine these with other stimulants.
\end{abstract}

\section{INTRODUCTION}

Energy drink (ED) products are carbonated, stimulantladen beverages. They most frequently contain taurine, arginine, caffeine, acidity regulators, various B vitamins, vitamin $\mathrm{C}$, herbal extracts, and sugar, as well as other sweetening substances._Many authors observe that the caffeine content of EDs is usually higher than that of a cup of coffee [2,21]. In Poland, energy drinks contain an average $32 \mathrm{mg}$ of caffeine in $100 \mathrm{ml}$ of drink, but additional amounts of caffeine can be found in the other ingredients of EDs, among these, kola nuts, guarana or yerba mate [17]. Regardless of the analyzed caffeine contents, EDs are usually consumed in larger quantities than coffee or other stimulating drinks. Moreover, the typical consumer of EDs are young people or even children. The caffeine and taurine contents of EDs purportedly assist in focusing attention, enhance the general mental functional capacity, and reduce the feeling of fatigue. This is why EDs are popular among people involved in hard physical labour, or those who wish to stay alert for longer periods of time, e.g. drivers, and students while studying.

\footnotetext{
* Corresponding author

e-mail: ewelina.wawryk@wp.pl
}

EDs are also popular at parties. These are frequently mixed with alcohol in order to enhance their effect. This action can result in an overdose, impaired cognitive functions and weaker symptoms of alcoholic intoxication $[17,18]$. Still, frequent consumption of EDs in large quantities may be dangerous for the health or life of the consumer. The observed side effects of ED over-consumption include: headaches, heart palpitations and arrhythmia, digestive system disorders, breathing problems and liver or kidney disorders $[6,8,15,16,20]$. Consumption by children may induce osseous mass effects, insomnia, cardiovascular diseases and mood and behavioral disorders $[6,17,20]$. According to current literature, the risk of negative consequences is higher in certain populations, including children, pregnant women (risk of late miscarriages, impaired fetal growth) and people with underlying cardiac conditions or diabetes mellitus. Despite the possibility of serious consequences, EDs in Poland are sold in most grocery stores or general shops, and likened as being a kind of soft drink. The annual market share of EDs in the USA has reached 20 billion USD [9] and in Poland, in 2013, this figure was 765 million PLN and has increased since [7]. The phenomenal popularity of 
EDs has attracted the attention of many consumer researchers throughout the world. Those involved in such have analyzed preferences, consumption style, reasons of consumption, as well as their impact on the general health and mental condition. In Poland, such studies have been conducted among students of medical faculty of universities in Lodz, Bydgoszcz and Cracow and in the University of Life Sciences in Lublin. In our study, we assessed consumption and the awareness concerning EDs among the $1^{\text {st }}$ and $2^{\text {nd }}$ year students of Faculty of Medicine and Dentistry of the Medical University of Lublin.

\section{MATERIAL AND METHODS}

The ED consumption survey was conducted among 96 students of Medicine and 35 students of Dentistry at the Medical University of Lublin. It included 20 questions referring to their personal data (age, weight, height, sex and origin), the amount of EDs they had consumed, their consumption style (including whether or not they mixed EDs with alcohol or another substances), the occurrence of side effects, and the results of their consumption. The statistical analysis of the results was performed using Statistica 10 PL software, with the following nonparametric tests: the chi-square test, the Mann-Whitney U test, and the Fisher test. Statistical significance level of $p \leq 0.05$ was applied for all calculations.

\section{RESULTS}

In the study, 131 students were surveyed, including 79 women and 52 men. Of these, 93 were in their 1st year, and 38 were in their 2 nd year of university. The majority of the subjects $(75.19 \%)$ were born in cities, and only $24.81 \%$ of subjects were from rural areas. The age median was 20 (19-25 years old). Basing on the submitted weight and height, BMI (body mass index) was calculated for the subjects according to the formula BMI = weight $[\mathrm{kg}] /$ (height $[\mathrm{m}])^{2}$. The resulting mean BMI in the subjects was $21.63 \pm 2.70 \mathrm{~kg} / \mathrm{m}^{2}$ and ranged from 16.65 to $32.83 \mathrm{~kg} / \mathrm{m}^{2}$. Moreover, the majority of the subjects $(77.10 \%)$ had normal BMI $\left(18.5-24.99 \mathrm{~kg} / \mathrm{m}^{2}\right)$, and included in this figure were both women (77.22\% of all women) and men (76.92\% of all men). Of note: $13.92 \%$ of all women had BMI lower than normal (3 women were severely underweight with the BMI of $16.0-16.99 \mathrm{~kg} / \mathrm{m}^{2}$ ) [4]. As to overweight (BMI $25.0-29.99 \mathrm{~kg} / \mathrm{m}^{2}$ ), we observed such in $19.23 \%$ of all men and in $1.27 \%$ of all women. What is more, the BMI of one man indicated obesity (BMI 32.83). Seven students did not respond to this question.

Among the all surveyed subjects, 81 (61.83\%) declared an ED consumption. The average BMI in ED consumers was $21.75 \pm 3.04 \mathrm{~kg} / \mathrm{m}^{2}$, and in the ED non-consumers was $21.46 \pm 2.08 \mathrm{~kg} / \mathrm{m}^{2}$. The difference was not statistically significant (Mann-Whitney test, $\mathrm{p}=0.865571$ ). Of the urban subjects, $65.98 \%$ confirmed ED consumption. Among the subjects from rural areas, $50 \%$ of all people declared ED consumption. The difference was not statistically significant (chi-square test, $\mathrm{p}=0.106311$ ). The correlation between consumption and sex also was also not statistically significant (chi-square test, $\mathrm{p}=0.295261$ ), although we observed that the percentage of male consumers (67.31\% of all men) was higher than of women (58.23\% of all women). ED consumers presented a varied consumption pattern, that is they consumed different quantities of EDs at different rates. Figures 1 and 2 present the consumption frequency and quantity. The difference between the ED consumption frequency in the group of men and women was not statistically significant, $(p>0.05$ in the Mann-Whitney $U$ test for each interval). The consumed quantity varied from person to person, from 200 to $2000 \mathrm{ml}$, average $454.43 \pm 282.48 \mathrm{ml}$. The majority (78.48\%) confirmed a consumption of more than 250 to $749 \mathrm{ml}$ of EDs at one time, $8.86 \%$ of all users declared consumption under $250 \mathrm{ml}$, and more than 749 $\mathrm{ml}$ of asks ED consumers drank 12.66\%. The difference between one-time ED consumption quantity by the men and women was not statistically significant $(p>0.05$ in the Mann-Whitney U test).

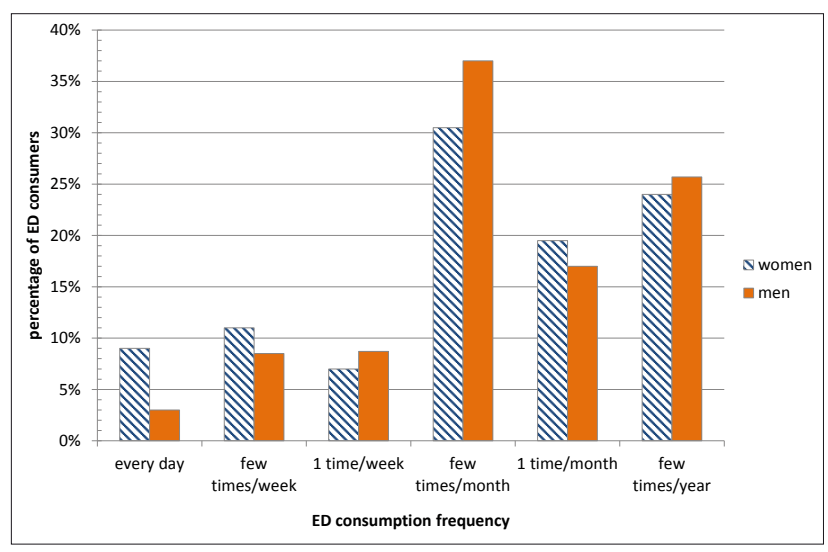

Figure 1. The ED consumption frequency in the group of men and women. The most of answered drank the ED few times per month. The difference between the ED consumption frequencyin the group of men and women was not statistically significant

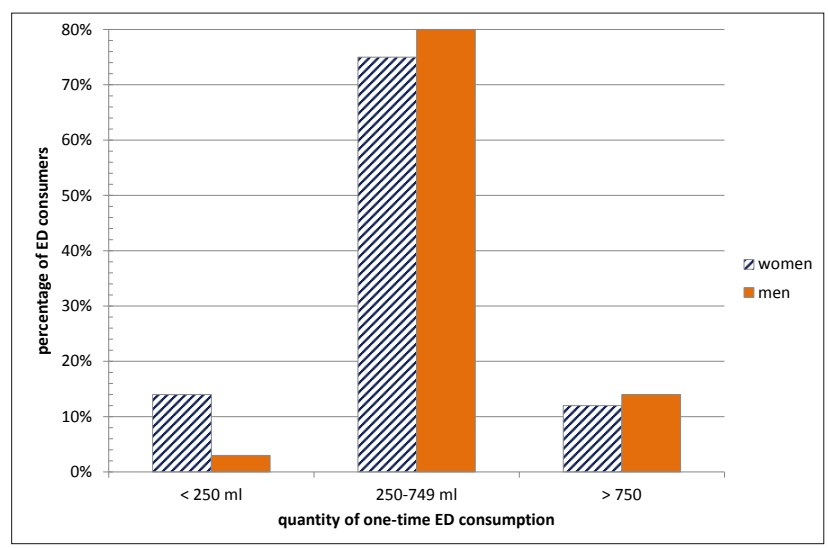

Figure 2. The quantity of one-time ED consumption in the group of women and the group of men

The survey also included questions concerning ED mixing with other substances. Most of respondents declared that they consumed EDs mixed with a few other substances. The number of subjects declaring such are presented in Table 1 . 
Table 1. The percentage of ED consumers which mix energy drinks with other substances

\begin{tabular}{|l|c|c|c|c|}
\hline \multirow{2}{*}{ Substance } & \multicolumn{2}{|c|}{ The percentage of ED consumers } & \multirow{2}{*}{$\begin{array}{c}\text { in chi-square } \\
\text { test }\end{array}$} \\
\cline { 2 - 4 } & $\begin{array}{c}\text { all ED } \\
\text { consumers }\end{array}$ & women & men & \\
\hline alcohol & $13.75 \%$ & $13.33 \%$ & $14.29 \%$ & 0.902338 \\
\hline cigarettes & $11.25 \%$ & $11.11 \%$ & $11.43 \%$ & 0.964443 \\
\hline designer drugs & $3.75 \%$ & $0 \%$ & $8.57 \%$ & $\mathbf{0 . 0 4 5 3 0 0}$ \\
\hline coffee & $17.50 \%$ & $13.33 \%$ & $22.86 \%$ & 0.266077 \\
\hline medication & $3.75 \%$ & $2.22 \%$ & $5.71 \%$ & 0.414746 \\
\hline
\end{tabular}

The data suggest a relatively infrequent mixing of EDs with other substances. A consumption of any of the listed substances, together with Eds, was declared by $26.25 \%$ of those surveyed who declared an ED consumption (22.22\% of all women and $31.43 \%$ of all male consumers, $p=0.35398$ in the Chi-square test). Coffee and alcohol were stated as being consumed most frequently together with EDs.

The following questions concerned the impact of EDs on their consumers' health, such consumers' knowledge about EDs and the opinion about their accessibility (Table 2). Almost half of all respondents believed that the availability of ED in Poland is right, the others hold that it should be limited.

Table 2. The experience with consumption of ED and knowledge about these beverages in the group of men and women

\begin{tabular}{|c|c|c|c|c|}
\hline \multirow{2}{*}{ Question } & \multicolumn{3}{|c|}{$\begin{array}{c}\text { The percentage of respondents who } \\
\text { answered "YES" }\end{array}$} & \multirow{2}{*}{$\begin{array}{c}\mathrm{p} \text { in chi-square } \\
\text { test } \\
\text { (difference between } \\
\text { men and women) }\end{array}$} \\
\hline & $\begin{array}{c}\text { all } \\
\text { respondents }\end{array}$ & women & men & \\
\hline $\begin{array}{l}\text { "Have you ever } \\
\text { experienced any } \\
\text { side effects of } \\
\text { EDs?" }\end{array}$ & $43.21 \%$ & $50.00 \%$ & $34.00 \%$ & 0.157278 \\
\hline $\begin{array}{l}\text { "Have the } \\
\text { experienced side } \\
\text { effects discouraged } \\
\text { you from further } \\
\text { consumption of } \\
\text { EDs?" }\end{array}$ & $25.71 \%$ & $21.74 \%$ & $33.33 \%$ & 0.456308 \\
\hline $\begin{array}{l}\text { "Do you know } \\
\text { the ingredients of } \\
\text { EDs?" }\end{array}$ & $78.63 \%$ & $70.89 \%$ & $90.38 \%$ & 0.007733 \\
\hline $\begin{array}{l}\text { "Do you know the } \\
\text { effects of energy } \\
\text { drinks?" }\end{array}$ & $86.26 \%$ & $81.01 \%$ & $94.23 \%$ & 0.031553 \\
\hline $\begin{array}{l}\text { "Do you know the } \\
\text { side effects of EDs" }\end{array}$ & $61.83 \%$ & $51.90 \%$ & $76.92 \%$ & 0.003919 \\
\hline $\begin{array}{l}\text { "Do you think that } \\
\text { ED availability in } \\
\text { Poland is right?" }\end{array}$ & $41.75 \%$ & $37.97 \%$ & $50.00 \%$ & 0.173450 \\
\hline
\end{tabular}

Further questions concerned their knowledge of contraindications. The results are presented in Table 3 (this was a multiple choice question).

Table 3. The knowledge of contraindications to energy drinks consumption in the group of men and women

\begin{tabular}{|c|c|c|c|c|}
\hline \multirow{2}{*}{$\begin{array}{c}\text { Answers for } \\
\text { question: "For who } \\
\text { energy drinks are } \\
\text { contraindicated?" }\end{array}$} & \multicolumn{3}{|c|}{$\begin{array}{c}\text { The percentage of respondents who } \\
\text { answered "YES" }\end{array}$} & \multirow{2}{*}{$\begin{array}{c}\mathrm{p} \text { in chi-square } \\
\text { test } \\
\text { (difference between } \\
\text { men and women) }\end{array}$} \\
\hline & $\begin{array}{c}\text { all } \\
\text { respondents }\end{array}$ & women & men & \\
\hline $\begin{array}{l}\text { children under } 18 \\
\text { years old }\end{array}$ & $65.65 \%$ & $68.35 \%$ & $61.54 \%$ & 0.421539 \\
\hline pregnant women & $93.89 \%$ & $94.94 \%$ & $92.31 \%$ & 0.538675 \\
\hline $\begin{array}{l}\text { people with gastric } \\
\text { or duodenal } \\
\text { disorders }\end{array}$ & $72.52 \%$ & $73.42 \%$ & $71.15 \%$ & 0.776424 \\
\hline $\begin{array}{l}\text { people with } \\
\text { hypertension }\end{array}$ & $79.23 \%$ & $76.92 \%$ & $82.69 \%$ & 0.426964 \\
\hline $\begin{array}{l}\text { people drinking } \\
\text { coffee }\end{array}$ & $45.80 \%$ & $49.37 \%$ & $40.38 \%$ & 0.312695 \\
\hline $\begin{array}{l}\text { people with } \\
\text { diabetes mellitus }\end{array}$ & $64.89 \%$ & $65.82 \%$ & $63.46 \%$ & 0.781768 \\
\hline other & $5.8 \%$ & $3.8 \%$ & $5.8 \%$ & 0.485735 \\
\hline
\end{tabular}

The final part of the survey concerned the consumption preferences of the subjects. This part of the survey included questions about the reasons for ED consumption and the location of the purchase of EDs. For the answer to the question about the reasons for ED consumption, the subjects either selected from the options provided in the survey or were allowed to give other reasons. The numbers representing ED consumption for specific reasons are presented in Table 4.

Table 4. The reasons for ED consumption in the group of men and women

\begin{tabular}{|c|c|c|c|c|}
\hline \multirow{2}{*}{ Reasons } & \multicolumn{3}{|c|}{$\begin{array}{l}\text { Percentage of ED consumers which use } \\
\text { its in follows reasons }\end{array}$} & \multirow{2}{*}{$\begin{array}{l}\mathrm{p} \text { in chi-square } \\
\text { test } \\
\text { (difference between } \\
\text { men and women) }\end{array}$} \\
\hline & $\begin{array}{c}\text { all } \\
\text { respondents }\end{array}$ & women & men & \\
\hline $\begin{array}{l}\text { improvement of } \\
\text { physical activity }\end{array}$ & $8.75 \%$ & $4.44 \%$ & $14.29 \%$ & 0.122262 \\
\hline $\begin{array}{l}\text { improvement of } \\
\text { mental agility }\end{array}$ & $46.25 \%$ & $51.11 \%$ & $40.00 \%$ & 0.322762 \\
\hline $\begin{array}{l}\text { overcome } \\
\text { sleepiness }\end{array}$ & $75.00 \%$ & $77.78 \%$ & $71.43 \%$ & 0.515305 \\
\hline $\begin{array}{l}\text { increased } \\
\text { concentration span } \\
\text { while studying }\end{array}$ & $30.00 \%$ & $28.89 \%$ & $31.43 \%$ & 0.805757 \\
\hline $\begin{array}{l}\text { improvement } \\
\text { physical ability } \\
\text { during sporting } \\
\text { events }\end{array}$ & $2.5 \%$ & $0 \%$ & $5.71 \%$ & 0.104377 \\
\hline $\begin{array}{l}\text { other } \\
\text { reasons }\end{array}$ & $8.75 \%$ & $6.67 \%$ & $11.43 \%$ & 0.482259 \\
\hline
\end{tabular}

\section{DISCUSSION}

Actual ED marketing began in Austria, in 1987, and in the United States, in 1997, when Red Bull was introduced [6, 13]. Presently, EDs are becoming a popular consumer good all over the world. In Poland, EDs were introduced in the 1990s, and their market share is still increasing. Their popularity (especially among young people), and their contents: caffeine, taurine, sweetening substances, and patented herbal extracts (of unknown effect), have made them the focus of attention of numerous researchers. The main research tool applied is the survey $[4,11,19]$.

The aim of the present survey was the evaluation of the consumption and awareness of EDs among medicine and dentistry students in Lublin. The survey was carried out among 131 students of the Faculty of Medicine and Dentistry of Medical University of Lublin. The data analysis revealed that EDs are popular among the subjects, and $61.83 \%$ of the surveyed confirmed their consumption. The acquired values are similar to those concerning other universities and presented by other authors. Kopacz et al. states that among the students of Warsaw University of Life Sciences, $67 \%$ of all students surveyed consume EDs [11]. Among the students of the Collegium Medicum of Bydgoszcz, $73 \%$ of all students consumed ED, and, among the students of the Medical University of Lodz, $76 \%$ take in EDs, as shown the study of Garus-Pakowska et al. [7]. Regarding Polish adolescents of junior high schools and senior high school attendance, $67 \%$ of all students have declared ED consumption [17]. As to the United States of America, the values referring to ED consumers fluctuate from $24 \%$ (O'Brien 2008) to $70 \%$ [19], while the results of a survey conducted among the students of the Marmara University Medical School in Istanbul, Turkey gave the result of $32 \%$ of the survey population declaring Eds consumption. In addition, ED consumption among medical students in 
South Africa is at the level of $36 \%$ of all the student body [12], and in Ghana [5], e ED consumption was declared by $62.2 \%$ of all students surveyed. Regarding Ed consumption, the record-breaking results were achieved in the United Arab Emirate, where $92 \%$ of all surveyed students declared ED consumption [10].

The present study indicated lack of a clear correlation between the ED consumption and the sex, origin or body weight expressed by the BMI. On the contrary, the research conducted by Marcinkowska et al. (2014) revealed the presence of a significant positive correlation between the consumption of sweetened fizzy drinks and the BMI $(\mathrm{p}=0.017)[14]$.

The most frequently declared reason for ED consumption among the surveyed subjects was the need to overcome sleepiness. This reason was put forward by $75.0 \%$ of the surveyed subjects. Thus, the need for the improvement of mental agility was specified by $46.25 \%$ of all ED drinkers, physical activity by $8.75 \%$ of them, and an increased concentration span while studying by $30 \%$ of all consumers. Our observation is consistent with the survey results obtained by other authors. Kopacz et al. reported that the need to overcome sleepiness and to improve mental performance were the most frequently declared reasons for ED consumption among students, especially during the examination period [11]. Similar results were obtained by other Polish authors. In the study of Chuda et al., $47 \%$ of all participants consumed energy drinks in order to improve mental performance while studying and $47 \%$ did so to increase general levels of physical and mental energy [6]. In the study of Semeniuk, $54.7 \%$ of all students consumed ED to eliminate sleepiness, $48 \%$ of all students declared consumption of energy drinks to improve mental performance, $32.7 \%$ of all surveyed did so to increase the physical capacity of the organism and $16 \%$ of the total surveyed population consumed such for mood improvement [22]. In the study of Garus-Pakowska et al., the participating students took in EDs when they felt tired (35\%) and during greater mental $(32 \%)$ or physical (9\%) effort) [22].

Numerous studies put forward that ED consumption frequently accompanies alcohol consumption, the smoking of cigarettes, the taking of medication, as well as other stimulating substances [3]. In the study of Nowak et al., nearly $10 \%$ of of the surveyed (teenagers) had energy drinks at parties, and 24\% admitted to mixing EDs with alcohol [17]. Of note: Gunja and Brown claim that such a situation may be relevant for more than 1/3 of all ED consumers [8]. Allied with the aforementioned, Garus-Pakowska indicated that $47 \%$ of the asked students drank ED together with alcohol [7], while in the study of Chuda et al., 10\% of all surveyed students mixed EDs with alcohol [6]. In our study, $26 \%$ of the surveyed declared a joined consumption of ED and other stimulating substances. The latter include alcohol (13.75\%), cigarettes (11.25\%), designer drugs (3.75\%), coffee $(17.5 \%)$ and certain medicaments $(3.75 \%)$.

The majority of all studies of energy drink consumption also dealt with an assessment of the knowledge of the surveyed about energy drinks. This level appears to be high. However, high knowledge about the harmfulness and about the side effects of ED consumption does not decrease usage of these beverages by young people. In our study, $86.26 \%$ of all the surveyed students knew about the effects of ED usage, $78.63 \%$ knew the ingredients of EDs, and $61.83 \%$ knew about their side effects when consumed, while $43.21 \%$ of all the surveyed had actual experience of some of these side effects. Still, just $25.71 \%$ of the surveyed declared that the experienced side effects had discouraged them from further ED consumption.

In the study of Chuda et al., almost half (48\%) of the consumers had observed the diverse side effects of ED consumption [6]. The most common symptoms were heart palpitations (observed by $48 \%$ of all students surveyed) and significant stimulation and tremors/trembling of their hands $(20 \%)$, less often, the surveyed consumers had experienced headaches $(9 \%)$, disorders of the gastrointestinal tract and breathing problems (5\%) [6]. A similar breakdown of symptoms was seen in the study of Semeniuk. In this study, $50.7 \%$ of the respondents had observed an acceleration of their heart rates. Moreover, $35.3 \%$ of all students surveyed had observed excessive mental stimulation and heightened aggression, and $34.7 \%$ had experienced sleeplessness [22]. Observation of these worrisome symptoms tend to expand the research regarding the increased risk of aggressive behaviors, including unprotected sex, substance abuse and violence within ED consumers [6]. In the study of O'Brien et al., students who reported common consumption of EDs had significantly higher prevalence of alcohol-related consequences, including being taken advantage of sexually, taking advantage of another sexually, riding with an intoxicated driver, being physically hurt or injured, and requiring medical treatment [18]. Publication of the aforementioned results should be the basis for the introduction of a limit in the ED market among some groups of population. In the our study, we evaluated the awareness of students concerning ED contraindications. The conviction that EDs should not be consumed by pregnant women was the one most frequently stated (93.89\%), while hypertension $(79.23 \%)$, gastric and duodenal disorders $(72.52 \%)$, and being of an age below $18(65.65 \%)$ or being afflicted with diabetes mellitus $(64.89 \%)$ were also enumerated as the contraindicating factors for ED consumption. Moreover, $58.25 \%$ of respondents think that ED marketing should be limited.

The survey showed that the phenomenon of ED consumption is known to the students of the Medical University of Lublin. What is important, a relatively large number of students have an awareness of the effects and possible consequences of ED consumption, nevertheless, they have an inclination for risky behaviors such as mixing EDs with other stimulating substances or consuming them in large quantities. The fact that only one half of the surveyed subjects noticed the need for limiting access to EDs in case of children, may be the result of an inadequate knowledge concerning the level of ED consumption among youth, and the impact they have on the growing and developing body. That is why it is important to share that knowledge concerning EDs among young parents or parents-to-be. Additionally, present students of all medical faculties should demonstrate profound knowledge concerning the avoidance of high consumption of EDs and set out other health-promoting 
behaviours amongst their peers and those whom they will encounter in their professional lives.

We declare the non-existence of any relationships (conflict of interests) that could affect the objectivity and credibility of the work.

\section{REFERENCES}

1. Alsunni A.A., Badar A.: Energy drinks consumption pattern, perceived benefits and associated adverse effects amongst students of University of Dammam, Saudi Arabia. J Ayub Med Coll Abbottabad 23(3) 3-9, 2011.

2. Arria A.M., O’Brien M.C.: The "high" risk of energy drinks. JAMA, 305(6), 600-601, 2011.

3. Azagba S., Sharaf M.F.: Is alcohol mixed with energy drinks consumption associated with susceptibility to smoking? Preventive Medicine, 61 26-28, 2014.

4. Brisbois T.D., Farmer A.P., McCargar L.J.: Early markers of adult obesity: a review. Obes Rev., 13(4), 347-67, 2012.

5. Buxton C., Hagan J.E.: A survey of energy drinks consumption practices among student - athletes in Ghana: lessons for developing health education intervention programs. J Int Soc Sports Nutr, 9, 9, 2012.

6. Chuda A., Lelonek M.: Badanie spożycia napojów energetyzujących wśród studentów IV i V roku Wydziału Lekarskiego Uniwersytetu Medycznego w Łodzi. Folia Cardiologica, 10, 149-156, 2015.

7. Garus-Pakowska A. et al.: Characteristics of energy drink consumption among students of selected medical universities. Probl Hig Epidemiol, 96(4), 776-781, 2015.

8. Gunja N., Brown J. A.: Energy drinks. Health risks and toxicity. Med J Aust, 196, 46-49, 2012.

9. Heckman M.A., Sherry K., Gonzalez De Mejia E.: Energy drinks: an assessment of their market size, consumer demographics, ingredient profile, functionality, and regulations in the United States. Comp Rev Food Sci Saf. 303-317, 2010.
10. Jacob S. et al: Consumption pattern of nutritional health drinks and energy drinks among university students in Ajman, UAE. Gulf Medical Journal, 2(1):22-26, 2013.

11. Kopacz A. et al.: Badania uwarunkowań spożywania napojów energetyzujących przez studentów. Rocz. Panstw. Zakl. Hig. 63, 4, 491-497, 2011.

12. Lee K.H. et al.: Medical students use of caffeine for academic purposes and their knowledge of its benefits, side-effects and withdrawal symptoms. SA Fam. Pract, 51(4):322-327, 2009.

13. Malinauskas B.M. et al.: A survey of energy drink consumption patterns among college students. Nutr J., 6, 35, 1-7, 2007.

14. Marcinkowska U. et al.: Zmiany w konsumpcji napojów wśród młodzieży. Probl Hig Epidemiol, 95(4), 907-911, 2014.

15. Menci D. et al.: Acute Effects of an Energy Drink on Myocardial Function Assessed by Conventional Echo-Doppler Analysis and by Speckle Tracking Echocardiography on Young Healthy Subjects. J. of Amino Acids, 1-7, 2013.

16. Nordt S. P. et al.: Energy drink use and adverse effects among emergency department patients. J Community Health, 37, 976-981, 2012 .

17. Nowak D., Jasionowski A.: Analysis of the Consumption of Caffeinated Energy Drinks among Polish Adolescents. Int J Environ Res Public Health, 12(7), 7910-7921, 2015.

18. O’Brien M.C.: Caffeinated cocktails: energy drink consumption, high-risk drinking, and alcohol-related consequences among college students. Acad Emerg Med, 15, 453-460, 2008.

19. Pettit M.L., DeBarr K.A.: Perceived stress, energy drink consumption, and academic performance among college students. J Am Coll Health, 59(5), 335-341, 2011.

20. Rácz A., Héberger K., Fodor M.: Quantitative determination and classification of energy drinks using near-infrared spectroscopy. Anal Bioanal Chem., 408(23), 6403-11, 2016.

21. Reissig C.J., Strain E.C., Griffiths R.R.: Caffeinated energy drinks - a growing problem. Drug Alcohol Depend. 99, 1-10, 2009.

22. Semeniuk W.: Spożywanie napojów energetyzujących wśród studentów Uniwersytetu Przyrodniczego w Lublinie. Consumption of energy drinks among students of the University of Life Sciences in Lublin. Probl Hig Epidemiol, 92, (4), 965-968, 2011. 